University of Nebraska - Lincoln

DigitalCommons@University of Nebraska - Lincoln

2009

\title{
Perchlorate in Wet Deposition Across North America
}

Srinath Rajagopalan

Texas Tech University

Todd A. Anderson

Texas Tech University, todd.anderson@ttu.edu

Stephen Cox

Texas Tech University

Greg Harvey

U.S. Air Force Air Force Material Command ASC/ENVR

Qiuqiong Cheng

University of Pittsburgh

See next page for additional authors

Follow this and additional works at: https://digitalcommons.unl.edu/usafresearch

Part of the Aerospace Engineering Commons

Rajagopalan, Srinath; Anderson, Todd A.; Cox, Stephen; Harvey, Greg; Cheng, Qiuqiong; and Jackson, W. Andrew, "Perchlorate in Wet Deposition Across North America" (2009). U.S. Air Force Research. 34.

https://digitalcommons.unl.edu/usafresearch/34

This Article is brought to you for free and open access by the U.S. Department of Defense at DigitalCommons@University of Nebraska - Lincoln. It has been accepted for inclusion in U.S. Air Force Research by an authorized administrator of DigitalCommons@University of Nebraska - Lincoln. 


\section{Authors}

Srinath Rajagopalan, Todd A. Anderson, Stephen Cox, Greg Harvey, Qiuqiong Cheng, and W. Andrew Jackson 


\section{Perchlorate in Wet Deposition} Across North America

\author{
SRINATH RAJAGOPALAN, ${ }^{\dagger}$ \\ TODD ANDERSON, ${ }^{\ddagger}$ STEPHEN COX,

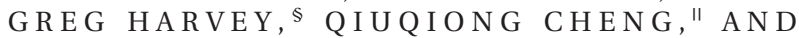 \\ W. A N D REW JACKS O N*, \\ Department of Civil and Environmental Engineering, Texas \\ Tech University, Lubbock, Texas 79409-1023, The Institute of \\ Environmental and Human Health, Texas Tech University, \\ Lubbock, Texas 79409-1163, U.S. Air Force Air Force Materiel \\ Command ASC/ENVR, Wright-Patterson AFB, Ohio 45433, \\ and Center for Pharmacogenetics, School of Pharmacy, \\ University of Pittsburgh, Pittsburgh, Pennsylvania 15261
}

Received June 24, 2008. Revised manuscript received September 29, 2008. Accepted November 18, 2008.

Natural perchlorate is believed to be of atmospheric origin, yet no systematic study has been conducted to evaluate perchlorate deposition rate and possible seasonal or spatial variations. This study evaluated perchlorate concentrations in weekly composite wet deposition samples acquired through the National Atmospheric Deposition Program from 26 sites across the continental United States, Alaska, and Puerto Rico for a $1-3$ year period. Perchlorate concentrations varied from $<5 \mathrm{ng} / \mathrm{L}$ to a high of $102 \mathrm{ng} / \mathrm{L}$ with a mean of $14.1 \pm 13.5 \mathrm{ng} / \mathrm{L}$ for the 1578 total samples. The annual perchlorate flux by site ranged from a low of 12.5 (TX) to $157 \mathrm{mg} /$ ha-year (NE) and averaged $65 \pm 30 \mathrm{mg} / \mathrm{ha}$-year for all sites. Perchlorate concentrations and flux in wet deposition were generally highest in May-August declining to lows in December-February. Average annual perchlorate flux was correlated $(r>0.5 ; p<0.001)$ with $\mathrm{Ca}^{2+}$, $\mathrm{K}^{+}, \mathrm{NH}_{4}{ }^{+}, \mathrm{NO}_{3}{ }^{-}, \mathrm{Cl}^{-}$, and $\mathrm{SO}_{4}{ }^{-2}$. Wet deposition rate of $\mathrm{ClO}_{4}{ }^{-}$ in the conterminous United States (excluding Alaska, Hawaii, and Puerto Rico) while diffuse, represents a potential annual net mass flux of $51000 \mathrm{~kg}$, a value comparable to the estimated annual environmental releases from other known $\mathrm{ClO}_{4}{ }^{-}$sources.

\section{Introduction}

Perchlorate $\left(\mathrm{ClO}_{4}^{-}\right)$contamination continues to be an important environmental issue due to its potential health impacts, the number of areas with impacted groundwater, and the possibility of new legislation. Perchlorate is primarily used as an oxidant in solid rocket propellants and to a lesser extent on a mass basis in flares, fireworks, and some explosives. In addition, other much smaller niche applications exist. Perchlorate is also found as a byproduct in hypochlorite salts and solutions, chlorates, and nitrate mined from the Atacama Desert. No federal regulation currently exists for $\mathrm{ClO}_{4}^{-}$, although EPA is considering a drinking water regulation. A reference dose of $0.7 \mu \mathrm{g} / \mathrm{kg}$-day has been proposed

* Corresponding author phone: (806) 7422801 (230); fax: (806) 742 3449; e-mail: andrew.jackson@ttu.edu.

${ }^{\dagger}$ Department of Civil and Environmental Engineering, Texas Tech University.

₹ The Institute of Environmental and Human Health, Texas Tech University.

${ }^{\S}$ U.S. Air Force Air Force Material Command ASC/ENVR.

"University of Pittsburgh. by the National Academy of Science which would equate to a drinking water concentration of $24.5 \mu \mathrm{g} / \mathrm{L}$ assuming drinking water as $100 \%$ of the source exposure (1). Interestingly, a recent study by the Centers for Disease Control and Prevention found a statistical relationship between circulating thyroid hormone concentration in women and $\mathrm{ClO}_{4}{ }^{-}$exposure even at intake rates that were significantly below the suggested reference dose (2). Exposure to $\mathrm{ClO}_{4}^{-}$can be by both intake of water and food including milk, leafy vegetables, fruit, and other items, although currently the source of this $\mathrm{ClO}_{4}^{-}$is not well understood (3-5).

Natural perchlorate has been known to exist for over a century but until recently was thought to only occur in the Atacama Desert (6). More recent work has shown that it is present in groundwater throughout the United States, generally at low concentrations $(7,8)$, although in the semiarid Southern High Plains of Texas, groundwater $\mathrm{ClO}_{4}{ }^{-}$concentrations exceeded $1 \mu \mathrm{g} / \mathrm{L}$ over very large areas $\left(>150000 \mathrm{~km}^{2}\right)$ and in some extreme cases exceeded $100 \mu \mathrm{g} / \mathrm{L}$ (9). These elevated concentrations were believed to be caused by flushing of atmospherically deposited $\mathrm{ClO}_{4}{ }^{-}$accumulated over many thousands of years by widespread irrigation. A more recent study has shown that a substantial reservoir of natural $\mathrm{ClO}_{4}{ }^{-}$exists in the vadose zone of arid and semiarid areas of the United States, and is capable of producing groundwater $\mathrm{ClO}_{4}^{-}$concentrations of concern (10). This subsurface $\mathrm{ClO}_{4}{ }^{-}$is associated with well studied $\mathrm{Cl}^{-}$bulges that are linked to atmospheric deposition since the last wet period in the western United States ( $\sim 10000$ years ago).

The occurrence of natural $\mathrm{ClO}_{4}{ }^{-}$in soil and groundwater is important in relation to both exposure and costs associated with remediation of anthropogenic releases. Numerous $\mathrm{ClO}_{4}{ }^{-}$ remediation efforts are underway across the United States. The occurrence of natural $\mathrm{ClO}_{4}{ }^{-}$in groundwater and soil can complicate site evaluation and in some cases could add significant costs when natural $\mathrm{ClO}_{4}^{-}$is assumed to be anthropogenic or where background concentrations are not well established leading to clean up goals below background concentrations.

Limited information is available concerning the processes responsible for natural $\mathrm{ClO}_{4}{ }^{-}$production. Perchlorate can be produced by heterogeneous reactions of $\mathrm{Cl}^{-}$with ozone or UV light and by electrical discharge in air, although no information is known concerning the rates of production or reaction pathways (11). $\mathrm{ClO}_{4}^{-}$has also been shown to be rapidly produced by irradiation $(254-350 \mathrm{~nm})$ of $\mathrm{ClO}^{-}$and $\mathrm{ClO}_{2}{ }^{-}$but not $\mathrm{ClO}_{3}{ }^{-}$although the overall significance of these reactions to atmospheric production is unknown (12). Stable isotopic studies suggest that $\mathrm{ClO}_{4}{ }^{-}$from the Atacama Desert was produced from at least one reaction with $\mathrm{O}_{3}$ due to its $\Delta{ }^{17} \mathrm{O}$ anomaly ( 10\%o) (13). More recent isotopic studies of apparent natural $\mathrm{ClO}_{4}{ }^{-}$from the high plains of Texas suggest that other production pathways may also be possible due to the unique stable isotope signature of this $\mathrm{ClO}_{4}{ }^{-}$compared to Atacama or anthropogenic $\mathrm{ClO}_{4}^{-}$(14). While the occurrence of natural $\mathrm{ClO}_{4}{ }^{-}$is now well established, its source and rate of deposition are not well understood. Currently, the only estimates of deposition are from studies that infer deposition based on concentrations in groundwater or soil, evaporation rates, and accumulation times $(7,10)$. Perchlorate in wet deposition has only been measured directly for a few samples $(11,15)$.

Defining the flux of $\mathrm{ClO}_{4}{ }^{-}$will allow an evaluation of the relative importance of surface versus atmospheric generation, an evaluation of the relative magnitude of the sources of natural $\mathrm{ClO}_{4}{ }^{-}$, and give an improved understanding of the 


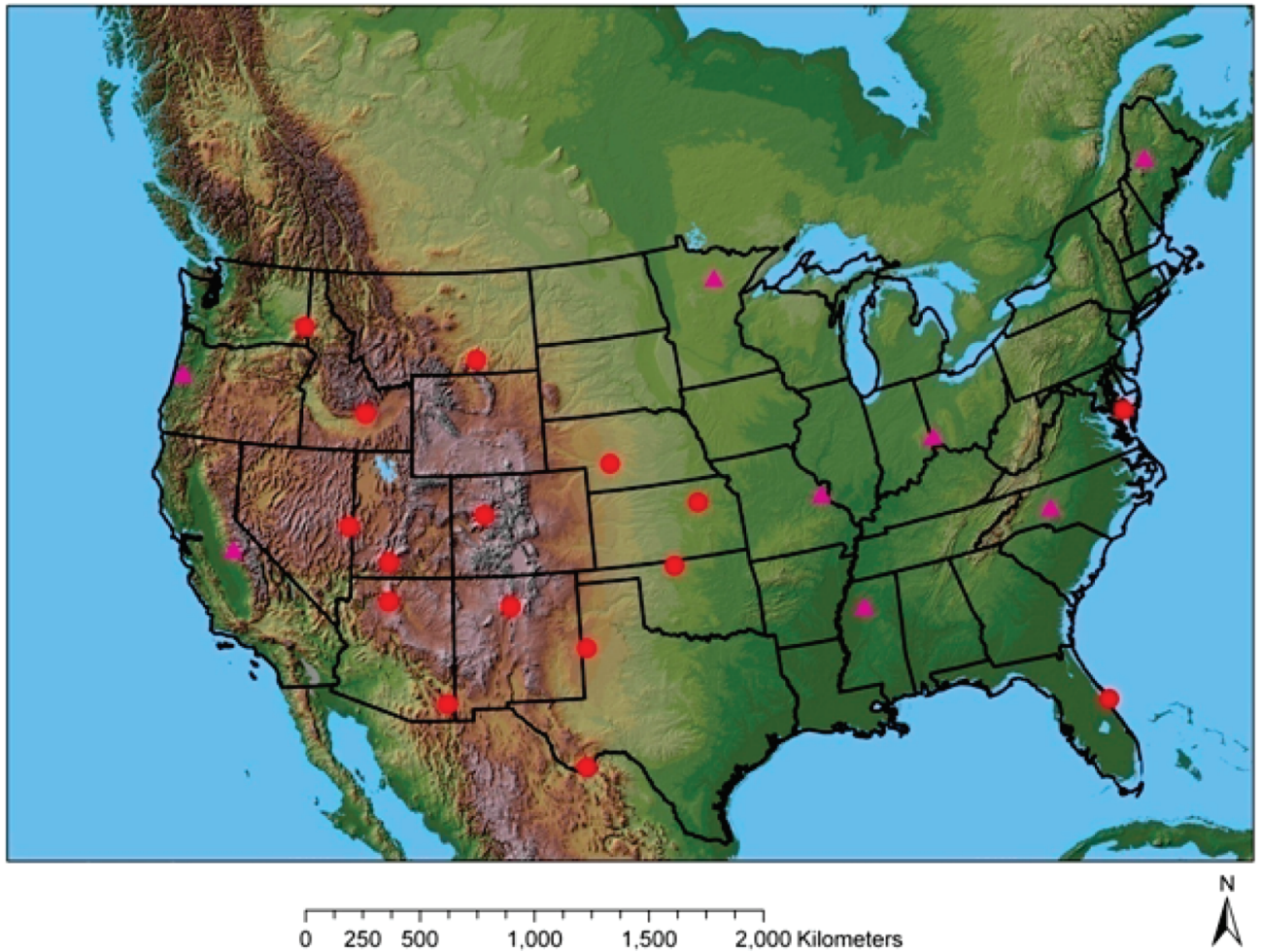

FIGURE 1. Locations of NADP sampling sites from which perchlorate concentrations were determined for 0ctober 2004 to 0 ctober 2007 (O) or only October 2006 to October 2007 (A). Puerto Rico and Alaska sites not shown.

biogeochemical cycle for $\mathrm{Cl}$ species which have been previously unstudied. The objectives of this study were to define the magnitude of the concentration and flux of $\mathrm{ClO}_{4}$ in wet deposition and its potential relationship to other atmospherically deposited species.

\section{Materials and Methods}

Wet deposition was evaluated over a three year period. Samples were obtained through the National Atmospheric Deposition Program (NADP). Perchlorate wet deposition was evaluated weekly at 16 NADP sites across the continental U.S. as well as Puerto Rico and Alaska for a 3 year period (October 2004 to October 2007). In addition, eight additional sites were evaluated in the third year of the study (Figure 1). Sites were originally weighted toward the southwestern United States in order to provide more detailed information on perchlorate deposition in semiarid and arid regions where $\mathrm{ClO}_{4}{ }^{-}$is most likely to be stable in the subsurface due to oxic conditions and where previous studies had shown large unsaturated zone $\mathrm{ClO}_{4}{ }^{-}$reservoirs (10). Puerto Rico was included due to its general isolation from any continental $\mathrm{ClO}_{4}{ }^{-}$sources, and Florida, Alaska, and Maryland were included to represent coastal areas. The eight sites added in the third year were selected to provide more complete geographical coverage and were largely located in the eastern United States. Two sites (Hawaii and Death Valley California) originally selected were discontinued by the NADP soon after the study began.

A total of 1578 subsamples of weekly composite wet deposition samples were evaluated. Samples were collected Tuesday to Tuesday of every week in ultra clean LPE plastic buckets provided on a weekly basis by Central Analytical Laboratory (CAL), operated by the Illinois State Water Survey in Champaign, Illinois. The samples for chemical analysis were collected using the commercially available Aerochem Metrics 301 precipitation collector (ACM). Samples were collected only during precipitation events; dry deposition was excluded. A Belfort rain gage was used at each site to independently determine wet deposition volume and duration of the events. Subsamples were shipped to Texas Tech University for $\mathrm{ClO}_{4}{ }^{-}$analysis. Concentrations of common ions chloride $\left(\mathrm{Cl}^{-}\right)$, nitrate $\left(\mathrm{NO}_{3}^{-}\right)$, ammonium $\left(\mathrm{NH}^{+}\right)$, sodium $\left(\mathrm{Na}^{+}\right)$, potassium $\left(\mathrm{K}^{+}\right)$, calcium $\left(\mathrm{Ca}^{2+}\right)$, and magnesium $\left(\mathrm{Mg}^{2+}\right)$ along with $\mathrm{pH}$ and conductivity (also measured at field sites) as well as weekly and annual wet deposition volumes were obtained directly from the NADP database available online (16). For further details on sample collection, handling, and analysis see NTN/NADP operational manual (17) and CAL SOP (18). Bulk samples (buckets open for the entire sampling period), invalid (failed the CAL QA/QC test), unidentified (buckets open for more the $6 \mathrm{~h}$ without wet deposition), and trace samples $(<0.15 \mathrm{~mm}$, sample volume $<10 \mathrm{~mL}$ ) were not analyzed for $\mathrm{ClO}_{4}^{-}$and were not considered for this study. Of the 3220 possible samples, 1840 (57\%) samples were valid wet deposition samples, 163 (5\%) samples were classified as trace ( $<10 \mathrm{~mL}$ volume), 490 samples were classified as invalid, and 730 samples were classified as dry samples (no wet deposition during the sampling period). Of the 1840 valid wet deposition samples, 1578 samples (86\%) were obtained and analyzed for $\mathrm{ClO}_{4}^{-}$(Supporting Information Table SI.1).

Perchlorate analysis used sequential ion chromatography-mass spectroscopy-mass spectroscopy (IC-MS/MS) with the limit of quantification (LOQ) of $5 \mathrm{ng} / \mathrm{L}$ (lowest calibration standard). A Dionex LC 20 ion chromatography system consisting of a GP50 pump, CD25 conductivity detector, AS40 automated sampler, Dionex IonPac AS16 (250 $\times 2 \mathrm{~mm}$ ) analytical column, and $0.1 \mathrm{~mL}$ injection loop was coupled with an Applied Biosystems, MDS SCIEX API 2000 triple quadrupole mass spectrometer equipped with a TurbolonSpray source. A $45 \mathrm{mM} \mathrm{NaOH}$ eluent at $0.3 \mathrm{~mL}$ $\mathrm{min}^{-1}$ was followed by $90 \%$ acetonitrile $\left(0.3 \mathrm{~mL} \mathrm{~min}^{-1}\right)$ as a postcolumn solvent. To overcome matrix effects, all samples were spiked with an oxygen-isotope $\left({ }^{18} \mathrm{O}\right)$ labeled $\mathrm{ClO}_{4}{ }^{-}$ internal standard. Perchlorate concentration was determined from the ratio of analyte $\left(\mathrm{ClO}_{4}^{-}\right)$peak area to internal standard 

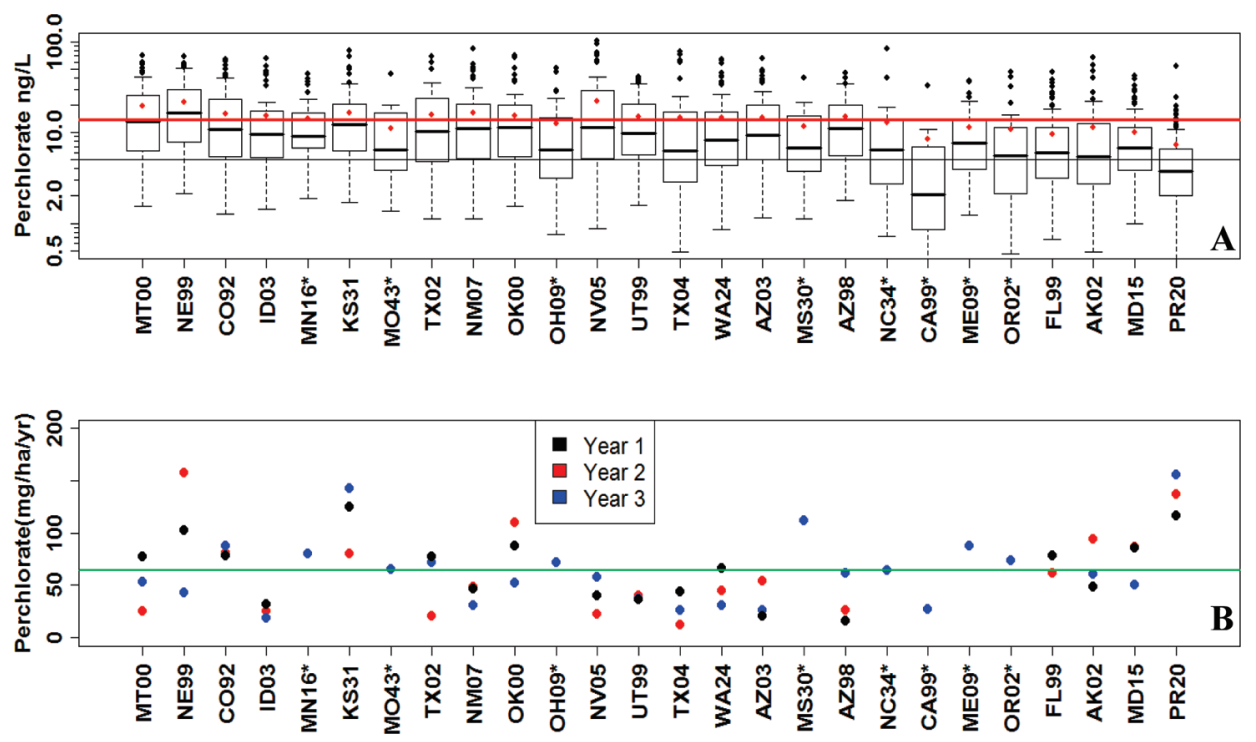

FIGURE 2. (A) Distribution of perchlorate concentrations in wet deposition by site. The upper and lower bar on each box represents the 75th and 25th percentile respectively. The middle bar represents the median and red dot the average. Black dots are sample concentrations that fall outside 1 standard deviation. Sites are arranged by increasing distance to the coast. The gray line represents the LOO and the red line the overall average concentration for all sites. (B) The annual flux of perchlorate by site for either the 3 year or 1 year collection period. The green line represents the average annual flux for all sites.

peak area. All analytical vials and pipet tips were triple rinsed in milli-Q water prior to use.

The first set of 670 samples were analyzed in batches of 10 followed by an analytical blank and check standard. About $10 \%(67)$ of the samples were randomly reanalyzed as an analytical replicate and an analytical spike. A batch was discarded if either the blank had quantifiable $\mathrm{ClO}_{4}{ }^{-}(>5 \mathrm{ng} /$ L) or if the check standard was off by more than $20 \%$. The check standard concentration varied between $5 \mathrm{ng} / \mathrm{L}$ and 40 $\mathrm{ng} / \mathrm{L}$. The average check standard recovery was $103 \pm 11 \%$ and the average analytical spike recovery was $99 \pm 17 \%$. The coefficient of variation (COV) for the analytical replicates was $10.3 \%$. The second subset of 400 samples was run in triplicate. Samples were run in batches of six samples followed by a spiked sample, analytical blank, and check standard (25 $\mathrm{ng} / \mathrm{L}$ ) in triplicate (33 samples). A batch was discarded if more than one blank had detectable $\mathrm{ClO}_{4}{ }^{-}$or if two or more check standards or the recovery of the spike varied by more than $20 \%$. The average check standard recovery was $102 \pm$ $11 \%$ with a COV of $5.8 \%$. The COV of the triplicate samples was $6.3 \%$. The average analytical spike recovery for this subset was $99 \pm 13.5 \%$. The final consignment of samples was analyzed in batches of 16 samples followed by an analytical replicate, spike, blank, and a check standard (varied from 5-50 ng/L). A batch was discarded if the blank had detectable $\mathrm{ClO}_{4}{ }^{-}$or if the check standard varied by more than $20 \%$. The average check standard recovery was $101 \pm 8 \%$ and the average analytical spike recovery was $98 \pm 11 \%$. The COV for analytical replicates was $4.7 \%$.

Over $32 \%$ (510) of the samples analyzed had no quantifiable $\mathrm{ClO}_{4}^{-}(<5 \mathrm{ng} / \mathrm{L})$. Traditionally, nondetects are substituted with one-half of the detection limit $(2.5 \mathrm{ng} / \mathrm{L})$. This technique introduces a left tail bias in the data set. Instead of substitution, the maximum likelihood estimation (MLE) method was used for estimating summary statistics and comparison of means. The MLE method uses detectable values, percent of data below the detection limit, and an assumed distribution. MLE is most effective for larger data sets that fit the assumed distribution (19). The MLE analysis for this data set, with assumed log-normal distribution was performed using NADA package in the statistical package $\mathrm{R}$. Wilcoxon Rank sum test was performed on the data set to examine the temporal and site-wise variation of average $\mathrm{ClO}_{4}{ }^{-}$ concentrations.

\section{Results and Discussion}

$\mathrm{ClO}_{4}{ }^{-}$Concentration and Flux. Perchlorate concentrations in wet deposition varied from $<5 \mathrm{ng} / \mathrm{L}$ to a high of $102 \mathrm{ng} / \mathrm{L}$ with a mean of 14.1 and standard deviation of $\pm 13.5 \mathrm{ng} / \mathrm{L}$ for the 1578 total samples (Figure 2). Average concentrations by site varied from a high of $21.9 \mathrm{ng} / \mathrm{L}$ (Nebraska and Nevada) to a low of $7.3 \mathrm{ng} / \mathrm{L}$ for Puerto Rico (Figure 2, and Supporting Information Table SI.2). Perchlorate annual flux by site ranged from a low of 12.5 (Texas) to $157 \mathrm{mg} /$ ha-year (Nebraska) and averaged $65 \pm 30 \mathrm{mg} /$ ha-year for all sites over the 3 year study period. $\mathrm{ClO}_{4}{ }^{-}$concentration data were log normally distributed; $32.3 \%$ of the samples were below the quantitation limit of $5 \mathrm{ng} / \mathrm{L}$. Seven sites were significantly different than the overall site mean ( $p<0.01$ ): three greater (Nebraska, Montana, Kansas) and four lower (Puerto Rico, Maryland, Florida, California). The four sites with lower than average $\mathrm{ClO}_{4}{ }^{-}$concentrations were all coastal with the exception of California. The California site was evaluated for 1 year and only produced 13 samples, while the next lowest number of samples collected for monitored sites over a 1 year period was 28 (Missouri). Sites monitored for 3 years produced from 51 to 117 samples for $\mathrm{ClO}_{4}^{-}$analysis (Supporting Information Table SI.1).

Overall, the concentrations observed in the present study were significantly lower than those reported by previous studies on $\mathrm{ClO}_{4}^{-}$in wet deposition. Dasgupta et al. (11) reported values for 25 samples collected in Lubbock, TX and one in Florida ranging from ND $(\mathrm{MDL}=10 \mathrm{ng} / \mathrm{L})$ to 1600 ng/L with nine samples below the detection limit and seven samples $<100 \mathrm{ng} / \mathrm{L}$. The analysis for these samples was by preconcentration IC-MS. Barron et al. (15) reported a concentration of $2800 \mathrm{ng} / \mathrm{L}$ for one sample out of 10 with four more estimated near $100 \mathrm{ng} / \mathrm{L}(\mathrm{LOQ}=249 \mathrm{ng} / \mathrm{L})$. The analysis method was preconcentration followed by ion chromatography with conductivity detection. Most recently, Parker et al. (8) reported the concentration of $\mathrm{ClO}_{4}^{-}$in 14 samples from nine sites in three states using IC-MS (internal isotopic standard but no secondary ion confirmation). Concentrations varied widely ( $<40-24400 \mathrm{ng} / \mathrm{L}$ ). Of the 14 samples, three were $<40 \mathrm{ng} / \mathrm{L}$, four were $\leq 100 \mathrm{ng} / \mathrm{L}$ with the 
remaining six samples $\geq 140 \mathrm{ng} / \mathrm{L}$. Our results are clearly much lower than $\mathrm{ClO}_{4}{ }^{-}$concentrations in these previous reports. Several explanations for this observation are possible. The previous studies used older analytical methods, whereas this study utilized the most definitive analytical method available, IC-MS-MS with an isotopic standard. Collection protocols also varied. In some cases (11) sample collection bottles were open to the atmosphere both before and after rain events possibly allowing contributions from dry deposition. For the most current study (8) no details are provided on sample collection, but at least in one instance, samples represented different time periods within a given storm and thus represent a time dependent concentration rather than an overall average concentration for the event. Samples collected in the present study represent the overall concentration of one week's total wet deposition and are therefore a better estimate of long-term depositional flux and surface impacts due to wet deposition.

Other studies have estimated long-term average concentrations of $\mathrm{ClO}_{4}^{-}$in wet deposition. Plummer et al. (7) predicted $\mathrm{ClO}_{4}^{-}$concentrations in wet deposition based on evapotranspiration-adjusted Holocene groundwater $\mathrm{ClO}_{4}{ }^{-}$ concentrations. Their estimates ranged from 19 to $93 \mathrm{ng} / \mathrm{L}$, much closer to those reported here especially when considering that their estimates included potential dry depositional fluxes, whereas concentrations reported here are for wet deposition only. Rao et al. (10) also estimated $\mathrm{ClO}_{4}{ }^{-}$ concentrations in wet deposition based on deep vadose reservoirs of $\mathrm{ClO}_{4}{ }^{-}$in the southwest that have accumulated since the last wet period ( $\sim 10000$ years ago). Assuming all $\mathrm{ClO}_{4}{ }^{-}$was deposited by wet deposition and no loss of $\mathrm{ClO}_{4}{ }^{-}$ occurred, they estimated $\mathrm{ClO}_{4}{ }^{-}$concentrations for the six sites ranging from 2 to $23 \mathrm{ng} / \mathrm{L}$ with an overall mean of 9 ng/L.

Natural $\mathrm{ClO}_{4}^{-}$background concentrations in groundwater can be estimated based on potential evapotranspiration (ET) and assuming no transformation, no contribution from dry deposition, or dissolution of stored atmospheric $\mathrm{ClO}_{4}^{-}$. In western areas where ET may reach extremes as high as 200 (7), groundwater concentrations could reach $2.8 \mu \mathrm{g} / \mathrm{L}$ but more generally (assuming an ET factor of 40) would approach $\sim 0.56 \mu \mathrm{g} / \mathrm{L} ; \mathrm{ClO}_{4}^{-}$background concentrations in more temperate climates would be much lower. These values are reasonably consistent with previous studies $(7,8)$. It should also be noted that these values represent the range of concentrations expected in unimpacted groundwater. In cases where irrigation of arid areas (e.g., agriculture, golf courses, lawns) may have flushed stored atmospheric salts, the concentrations could be much greater (9).

$\mathrm{ClO}_{4}{ }^{-}$in wet deposition in the conterminous United States (excluding Alaska, Hawaii, and Puerto Rico) while diffuse represents a potential annual net mass flux of 51000 $\mathrm{kg}$ assuming an average annual flux of $64 \mathrm{mg} / \mathrm{ha}-y e a r$ (average of annual fluxes for all sites excluding Alaska, Hawaii, and Puerto Rico) and a total area of $8 \times 10^{6} \mathrm{~km}^{2}$ for the lower 48 states. In comparison, annual U.S. $\mathrm{ClO}_{4}{ }^{-}$ industrial production is very roughly estimated at $10^{7} \mathrm{~kg}$, and current Chilean nitrate imports are estimated to contribute at most $15000 \mathrm{~kg}$ (assuming an import value of $1.5 \times 10^{8} \mathrm{~kg} / \mathrm{yr} \mathrm{NaNO}_{3}$ and a $\mathrm{ClO}_{4}{ }^{-}$concentration of $<0.01 \%$ ) (20). The produced $\mathrm{ClO}_{4}{ }^{-}$is primarily used for solid rockets with less than $2 \%\left(1.4 \times 10^{5}\right)$ used for flares and an unknown amount used for fireworks. Fireworks consumption in the U.S. was estimated at $1.8 \times 10^{7} \mathrm{~kg}$ in 2003 , most of which was imported (21). Assuming this is a typical year and an upper average $\mathrm{ClO}_{4}{ }^{-}$content of $50 \%$, an estimate of $9 \times 10^{6} \mathrm{~kg}$ of $\mathrm{ClO}_{4}{ }^{-}$is possible. It is not known how much of the $\mathrm{ClO}_{4}{ }^{-}$from solid rockets, flares, or fireworks is actually released to the environment. No estimate is available for the $\mathrm{ClO}_{4}^{-}$released from solid rockets during ignition although it is probable that most is used for its intended purpose (propulsion). Assuming $1 \%$ of the manufactured $\mathrm{ClO}_{4}{ }^{-}$is released, an annual input of $10^{5} \mathrm{~kg}$ /year would be expected. For flares, if only $50 \%$ is consumed, the $\mathrm{ClO}_{4}{ }^{-}$release would approximately equal $70000 \mathrm{~kg} /$ year. Fireworks are much more difficult to assess but assuming a 90 or $99 \%$ consumption rate would produce $\mathrm{ClO}_{4}{ }^{-}$releases approximately equal to $10^{5}-10^{6} \mathrm{~kg} /$ year. Other sources of $\mathrm{ClO}_{4}{ }^{-}$include hypochlorite and chlorate which contain $\mathrm{ClO}_{4}{ }^{-}$as an impurity. These sources are even more difficult to assess, however, using values from one source (20), $\mathrm{ClO}_{4}^{-}$production as an impurity in chlorate can be estimated at $50000 \mathrm{~kg} /$ year (assuming $10^{9} \mathrm{~kg} /$ year of chlorate and a $\mathrm{ClO}_{4}{ }^{-}$content of $0.005 \%$ ). These values are all highly speculative but are illustrative of potential relative source magnitudes.

Even taking into account the assumptions in the above analysis, $\mathrm{ClO}_{4}{ }^{-}$annual mass flux from wet deposition is likely a significant contributor to the occurrence of $\mathrm{ClO}_{4}{ }^{-}$in the environment. Anthropogenic sources generally represent very small areas compared to the continental U.S., excluding the contamination of the Colorado River and subsequent impact to Arizona and southern California. As such perchlorate in wet deposition as well as other nonpoint sources (fireworks, flares, chlorate, hypochlorite) could help to account for the frequency of exposure reported in the recent National Health and Nutrition Examination Survey (22) and the seemingly ubiquitous presence of $\mathrm{ClO}_{4}{ }^{-}$in food reported by the Food and Drug Administration (23).

Spatial and Temporal $\mathrm{ClO}_{4}^{-}$Variation. Perchlorate concentrations and flux (mg/ha $\cdot$ year) for the three year study period were generally highest in May-August declining to a low in December-February (Figure 3). This general trend was observed in 2005 and 2007 but not in 2006 (Supporting Information Figure SI.1) despite little change in the average annual $\mathrm{ClO}_{4}{ }^{-}$concentration $(16.5 \mathrm{ng} / \mathrm{L} \pm 16.3,12.5 \mathrm{ng} / \mathrm{L} \pm$ 11.3 , and $13.3 \mathrm{ng} / \mathrm{L} \pm 12.5$ for 2005,2006 , and 2007, respectively) or flux $(69.6 \mathrm{mg} / \mathrm{ha} \cdot$ year $\pm 28.5,48.1 \mathrm{mg} / \mathrm{ha} \cdot$ year \pm 32.1 , and $71.0 \mathrm{mg} / \mathrm{ha} \cdot$ year \pm 40 for 2005 , 2006, and 2007, respectively). Possible explanations for the elevated fluxes and concentrations in May-August include (1) higher tropospheric temperatures which could increase reaction rates; (2) more intense storms which may increase upper level mixing (stratospheric contribution) or may have increased lightning occurrence, a possible production mechanism; and (3) increased ozone concentrations or UV intensity both of which may contribute to perchlorate production $(11,12)$. However, it is not possible to evaluate these potential factors with the current data set. $\mathrm{NH}_{4}{ }^{+}, \mathrm{NO}_{3}{ }^{-}, \mathrm{Ca}^{2+}$, and $\mathrm{SO}_{4}{ }^{-2}$ also were seasonally dependent with similar seasonal distributions (Supporting Information Figure SI.2).

Perchlorate concentrations generally increased ( $r=0.77$; $p<0.001$ ) with distance from the coast. Concentrations of $\mathrm{Ca}^{2+}, \mathrm{NH}_{4}{ }^{+}, \mathrm{pH}$, and $\mathrm{NO}_{3}{ }^{-}$were also positively correlated $(r$ $=0.52,0.64,0.58,0.45$, respectively) with distance from the coast while $\mathrm{Cl}^{-}$was negatively correlated $(-0.56)$ (Supporting Information Figure SI.3). Site average concentrations decreased $(r=-0.60 ; p=0.002)$ with an increase in annual wet deposition (Figure 4 ). Some major ions also were correlated to annual wet deposition but in general the relationships were weaker and dominated by coastal sites (Supporting Information Figure SI.4). The decrease in $\mathrm{ClO}_{4}{ }^{-}$concentration with increasing annual wet deposition may simply be due to dilution and the positive relation between $\mathrm{ClO}_{4}{ }^{-}$concentration and distance from the coast due to the covariance of distance to the coast with annual wet deposition. Annual wet deposition decreases with distance from the coast, but after $200-400 \mathrm{~km}$ inward there is no further systematic decrease in wet deposition (Supporting Information Figure SI.5). Annual flux of $\mathrm{ClO}_{4}{ }^{-}$increased $(r=0.75 ; p=<0.0001)$ 


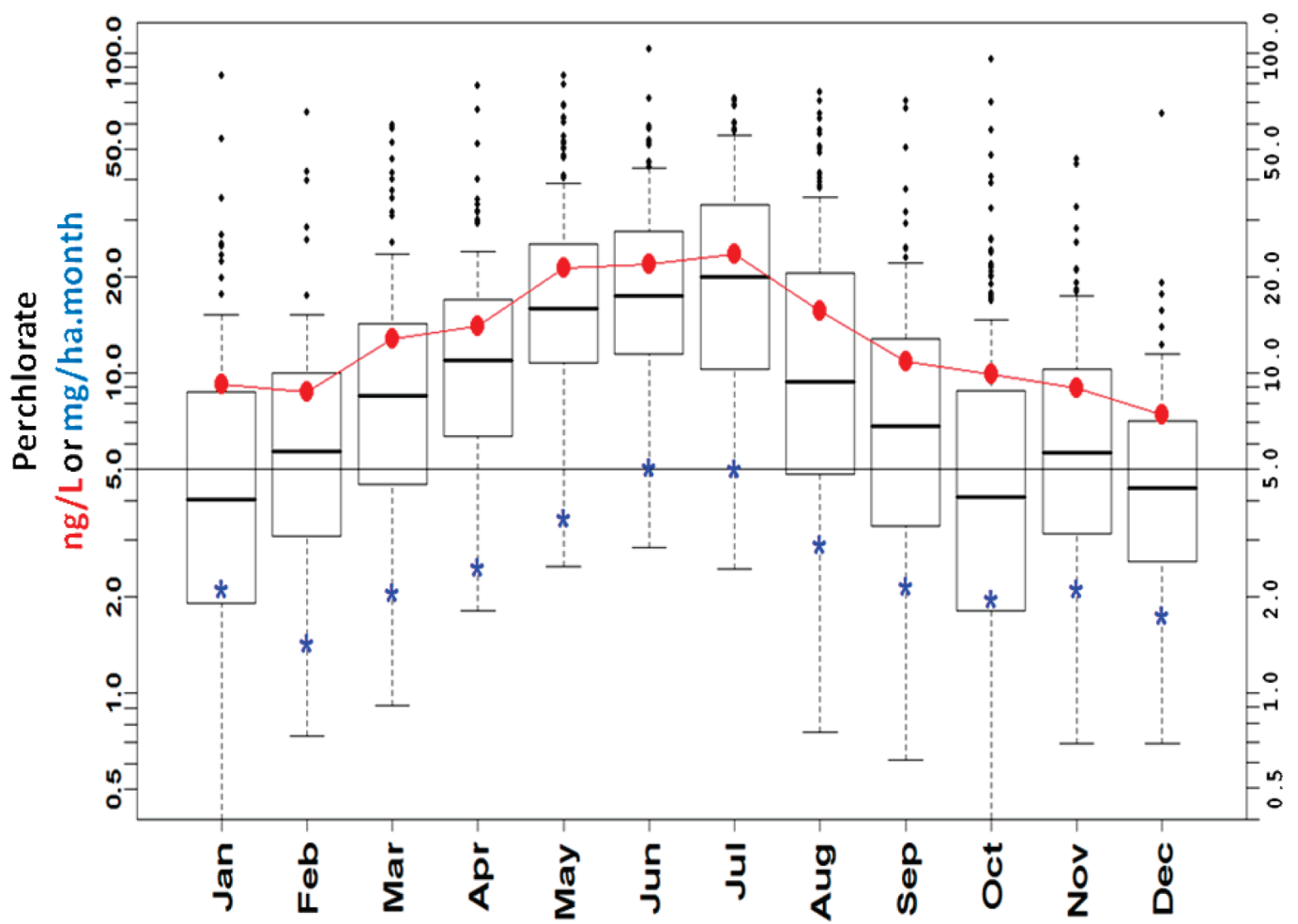

FIGURE 3. Monthly variation in perchlorate concentration and flux for all sites for the 3 year study period. The upper and lower bar on each box represents the 75th and 25th percentile concentration, respectively. The middle bar represents the median concentration and red dot the average concentration. Black dots are sample concentrations that fall outside 1 standard deviation. Monthly flux is represented by the blue star.

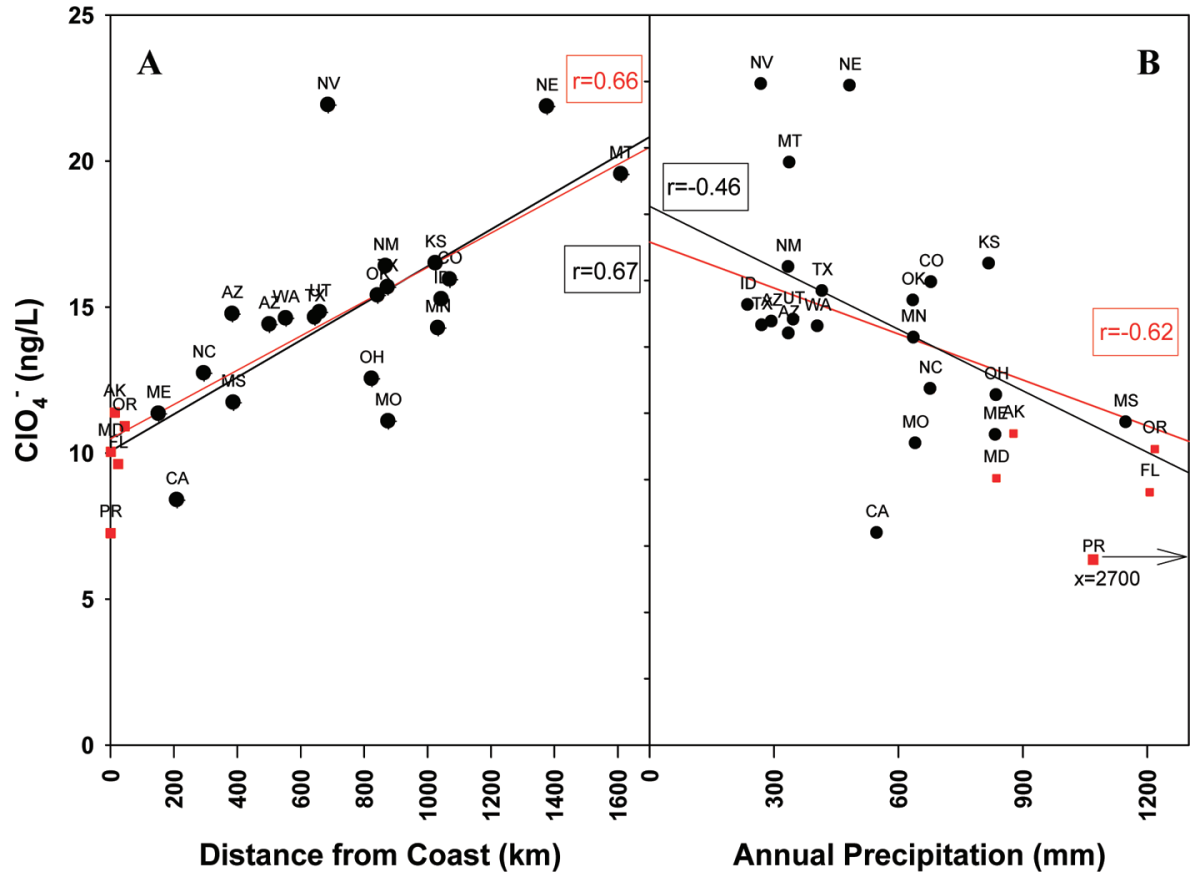

FIGURE 4. (A) Relationship between site average perchlorate concentrations (1 or 3 year average) and the shortest distance to coast in kilometers, and (B) average annual wet depositional flux for the corresponding collection period. Red dots are coastal sites and the red line is the regression line for all sites including coastal sites. The black line represents the regression line for the noncoastal sites.

with annual wet deposition (Figure 5) as did all major ions except $\mathrm{NH}_{4}{ }^{+}$(Supporting Information Figure SI.6) but there was no correlation with annual $\mathrm{ClO}_{4}{ }^{-}$flux and distance from the coast (Figure 5). Distance from the coast was also a poor predictor of major ion annual flux (Supporting Information Figure SI.7). Therefore, $\mathrm{ClO}_{4}{ }^{-}$flux appears to be controlled by the annual volume of wet deposition more than the concentration of $\mathrm{ClO}_{4}^{-}$in wet deposition.

Relation to other Atmospherically Deposited Species. The relationship of $\mathrm{ClO}_{4}{ }^{-}$concentration to the concentration of other ions (16) was determined by combining all sites for weekly samples. This comparison is best suited for under- 

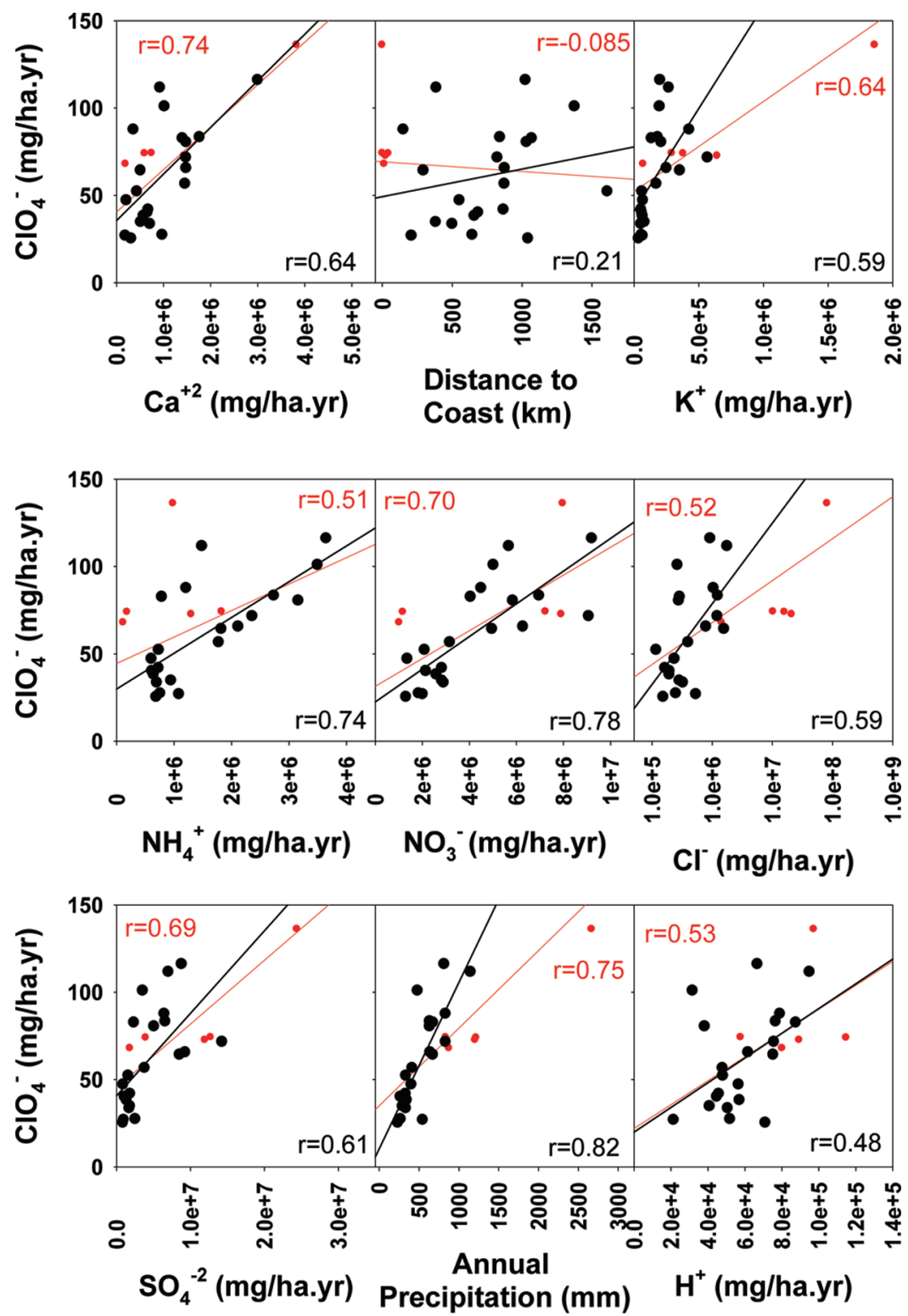

FIGURE 5. Relationship between site average perchlorate and other major ions (16) annual wet depositional flux (mg/ha.yr). Red dots represent coastal sampling sites. The red and black line represent the regression line for all sites (coastal and noncoastal) and noncoastal sites, respectively.

standing direct relationships between $\mathrm{ClO}_{4}{ }^{-}$and other ions rather than covarying relationships due to spatial location. Perchlorate is significantly $(p<0.001$ ) related to all other monitored ions $\left(\mathrm{Ca}^{2+}, \mathrm{Na}^{+}, \mathrm{K}^{+}, \mathrm{NH}_{4}^{+}, \mathrm{NO}_{3}{ }^{-}, \mathrm{Cl}^{-}, \mathrm{SO}_{4}{ }^{-2}\right.$, and $\mathrm{pH})$ except $\mathrm{Mg}^{2+}$, although the regression coefficients are generally quite low $(<0.3)$, except for $\mathrm{Ca}^{2+}, \mathrm{NH}_{4}{ }^{+}$, and $\mathrm{NO}_{3}{ }^{-}$ ( $r=0.40,0.41$, and 0.38 respectively) (Supporting Information Figure SI.8). A close examination reveals rather weak relationships but some interesting observations. Of those species with the highest correlation coefficients, there is a trend indicating that the highest $\mathrm{ClO}_{4}^{-}$concentrations tend to occur at the higher $\mathrm{Ca}^{2+}, \mathrm{NH}_{4}{ }^{+}$, and $\mathrm{NO}_{3}{ }^{-}$concentrations (Supporting Information Figure SI.8). This is also true of other less well correlated ions with the notable exception of $\mathrm{Cl}^{-}$, $\mathrm{Na}^{+}$, and $\mathrm{pH}$. Concentrations of $\mathrm{Cl}^{-}$and $\mathrm{ClO}_{4}^{-}$have a nonlinear inverse relationship dominated by the impact of coastal sites. $\mathrm{Cl}^{-}$and $\mathrm{Na}^{+}$are highly correlated $(r>0.99)$ and as such have identical relationships to $\mathrm{ClO}_{4}{ }^{-}$. Atmospheric $\mathrm{Cl}^{-}$while a possible precursor to $\mathrm{ClO}_{4}{ }^{-}$formation occurs at such high concentrations relative to $\mathrm{ClO}_{4}{ }^{-}$that it is unlikely to limit $\mathrm{ClO}_{4}^{-}$formation.
$\mathrm{SO}_{4}{ }^{-2}$ and $\mathrm{NO}_{3}{ }^{-}$should have no direct role in $\mathrm{ClO}_{4}^{-}$ formation but are oxyanions formed atmospherically and thus could possibly be associated with $\mathrm{ClO}_{4}{ }^{-}$production from atmospheric oxidative processes. $\mathrm{NO}_{3}{ }^{-}$and $\mathrm{SO}_{4}{ }^{-2}$ concentrations are correlated $(r=0.67)$ and high values are predominantly related to atmospheric pollution by stationary and nonstationary sources. However, the relatively weak relationship suggests that $\mathrm{ClO}_{4}{ }^{-}$formation mechanisms are not closely related to either oxyanion. The stronger relationship between $\mathrm{ClO}_{4}{ }^{-}$and $\mathrm{Ca}^{2+}$ and $\mathrm{NH}_{4}{ }^{+}$, two species with very little likelihood of being associated with oxidation mechanisms, suggests that the high $\mathrm{ClO}_{4}{ }^{-}$concentrations may be related to more general atmospheric pollution such as the introduction of particulates into the atmosphere. The more general trend (excluding $\mathrm{Cl}^{-}$and $\mathrm{Na}^{+}$) of the highest $\mathrm{ClO}_{4}{ }^{-}$concentrations occurring at the highest values of other ions also supports this possibility. It is also possible that these trends are simply due to dilution; large rain events tend to dilute the concentrations of all species.

Stronger relationships exist between $\mathrm{ClO}_{4}{ }^{-}$and other ions (16) if annual flux per site is used in place of concentration 
per event. This analysis compensates for the influence of wet deposition volume on concentration and is also more relevant in terms of surface accumulation. Perchlorate flux was correlated $(r>0.5 ; p<0.001)$ with $\mathrm{Ca}^{2+}, \mathrm{K}^{+}, \mathrm{NH}_{4}{ }^{+}, \mathrm{NO}_{3}{ }^{-}$, $\mathrm{Cl}^{-}$, and $\mathrm{SO}_{4}^{-2}$ whether coastal sites were included but $\mathrm{H}^{+}$ was only correlated $(r=0.53 ; p<0.0064)$ if coastal sites were included (Figure 5). Of particular note are the strong relationships with $\mathrm{NO}_{3}{ }^{-}, \mathrm{Ca}^{2+}$, and annual wet depositional flux $(r>0.7)$. This may not be surprising in that if wet deposition volume (either event volume or number of events) controls the flux of ions then all species will correlate. This implies that for the sites monitored in this study, flux of $\mathrm{ClO}_{4}{ }^{-}$and the other ions is controlled by the precipitation volume more than the concentration in precipitation. This is supported by the relatively high correlation coefficients between yearly ion flux and annual wet deposition volume (Supporting Information Figure SI.5). Regardless, it indicates that $\mathrm{ClO}_{4}{ }^{-}$in the unsaturated zone or groundwater should be related to conservative species $\left(\mathrm{Cl}^{-}\right)$assuming no other sources or transformation of $\mathrm{ClO}_{4}{ }^{-}$as has been previously shown $(7-10)$.

Excluding coastal sites (Puerto Rico, Maryland, Alaska, Florida, Oregon) the average $\mathrm{Cl} / \mathrm{ClO}_{4}{ }^{-}$molar ratio for all sites based on mass flux was $27000 \pm 17000$ and ranged from 7200 (Montana) to 69000 (North Carolina) (Supporting Information Figure SI.9). This is similar to values reported for Pleistocene and Holocene groundwater in New Mexico (7000-25 000) and lower than values reported for vadose zone salt bulges produced from long-term atmospheric deposition in the southwest $(74000-572000 ; \bar{X}=224000$ $\pm 46000)(7,10)$. However, the flux of $\mathrm{Cl}^{-}$from dry deposition has been estimated to be of similar magnitude as the flux of $\mathrm{Cl}^{-}$from wet deposition (24). No information is available concerning $\mathrm{ClO}_{4}^{-}$in dry deposition, but if it is negligible then the $\mathrm{Cl}^{-} / \mathrm{ClO}_{4}^{-}$molar ratios accounting for $\mathrm{Cl}^{-}$dry deposition would range from 14 000-140 000 similar to the lower end of the vadose zone samples and New Mexico groundwater. Given the paucity of data supporting the estimate of dry $\mathrm{Cl}^{-}$deposition, values are reasonably consistent although microbial transformation of perchlorate and dry deposition of perchlorate may still impact final groundwater and vadose zone ratios.

\section{Acknowledgments}

We acknowledge the Strategic Environmental Research and Development Program for its support of this research (EP1485) and the National Atmospheric Deposition Program for facilitating the acquisition of samples.

\section{Supporting Information Available}

The distribution of sampling events by site; sitewise summary statistics for perchlorate concentrations and flux in wet deposition; linear regression parameters and correlation coefficients for the relationship analyzed; site specific yearly concentration and flux ratios; seasonal variations in concentration and flux by year for $\mathrm{ClO}_{4}{ }^{-}$and $\mathrm{NO}_{3}{ }^{-}, \mathrm{SO}_{4}{ }^{-2}$ and $\mathrm{Cl}^{-}$; the relationship between annual wet depositional flux and distance from coast for our sites and monitored time period; and correlations between major ion concentrations or flux and wet deposition and distance to the coast.This material is available free of charge via the Internet at http:// pubs.acs.org.

\section{Literature Cited}

(1) NAS (National Academy of Sciences). Health Implications of Perchlorate Ingestion; National Academies Press: Washington, DC, 2005.
(2) Blount, B. C.; Pirkle, J. L.; Osterloh, J. D.; Valentin-Blasini, L.; Caldwell, K. L. Urinary perchlorate and thyroid hormone levels in adolescent and adult men and women living in the United States. Environ. Health Perspect. 2006, 14, 1865-1871.

(3) Kirk, A. B.; Martinelango, P. K.; Tian, K.; Dutta, A.; Smith, E. E.; Dasgupta, P. K. Perchlorate and iodide in dairy and breast milk. Environ. Sci. Technol. 2005, 39, 2011-2017.

(4) Sanchez, C. A.; Crump, K. S.; Krieger, R. I.; Khandaker, N. R.; Gibbs, J. P. Perchlorate and nitrate in leafy vegetables of North America. Environ. Sci. Technol. 2005, 39, 9391-9397.

(5) El-Aribi, H.; Le Blanc, Y. J.C.; Antonsen, S.; Sakuma, T. Analysis of perchlorate in foods and beverages by ion chromatography coupled with tandem mass spectrometry (IC-ESI- MS/MS). Anal. Chim. Acta 2006, 567, 39-47.

(6) Ericksen, G. E. Geology and Origin of the Chilean Nitrate Deposits, Prof. Paper 1188; U.S. Geological Survey: Washington, DC, 1981.

(7) Plummer, L. N.; Böhlke, J. K.; Doughten, M. W. Perchlorate in Pleistocene and Holocene groundwater in North-Central New Mexico. Environ. Sci. Technol. 2006, 40, 1757-1763.

(8) Parker, D. R.; Seyfferth, A. L.; Reese, B. K. Perchlorate in groundwater: A synoptic survey of "pristine" sites in the conterminous Unites States. Environ. Sci. Technol. 2008, 42, 1465-1471.

(9) Rajagopalan, S.; Anderson, T. A.; Fahlquist, L.; Rainwater, K. A.; Ridley, M.; Jackson, A. W. Widespread presence of naturally occurring perchlorate in high plains of Texas and New Mexico. Environ. Sci. Technol. 2006, 40, 3156-3162.

(10) Rao, B.; Anderson, T. A.; Orris, G. J.; Rainwater, K. A.; Rajagopalan, S.; Sandvig, R. M.; Scanlon, B. R.; Stonestrom, D. A.; Walvoord, M. A.; Jackson, W. A. Widespread natural perchlorate in unsaturated zones of the Southwest United States. Environ. Sci. Technol. 2007, 41, 4522-4528.

(11) Dasgupta, P. K.; Martinelango, P. K.; Jackson, W. A.; Anderson, T.A.; Tian, K.; Tock, R. W.; Rajagopalan, S. The origin of naturally occurring perchlorate: The role of atmospheric processes. Environ. Sci. Technol. 2005, 39, 1569-1575.

(12) Kang, N.; Anderson, T. A.; Jackson, W. A. Photochemical formation of perchlorate from aqueous oxychlorine anions. Anal. Chim. Acta 2006, 567, 48-56.

(13) Bao, H.; Gu, B. Natural perchlorate has a unique oxygen isotope signature. Environ. Sci. Technol. 2004, 38, 5073-5077.

(14) Bohlke, J. K.; Sturchio, N. C.; Baohua, G.; Horita, J.; Brown, G. M.; Jackson, W. A.; Batista, J.; Hatzinger, P. B. Perchlorate isotope forensics. Anal. Chem. 2005, 77 (23), 7838-7842.

(15) Barron, L.; Nesterenko, P. N.; Paull, B. Rapid on-line preconcentration and suppressed micro-bore ion chromatography of part per trillion levels of perchlorate in rainwater samples. Anal. Chim. Acta 2006, 567, 127-134.

(16) National Atmospheric Deposition Program Data Access. http:// nadp.sws.uiuc.edu/sites/ntnmap.asp? (accessed on 3/12/2008).

(17) National Trends Network Site Operation Manual, National Atmospheric Deposition Program Manual 1999-01c; National Atmospheric Deposition Program, Illinois State Water Survey: Champaign, IL, 1999.

(18) Central Analytical Laboratory Standard Operating Procedures; Central Analytical Laboratory of the National Atmospheric Deposition Program, Illinois State Water Survey: Champaign, IL, 2002.

(19) Helsel, D. R., Nondetects and Data Analysis: Statistics for Censored Environmental Data; John Wiley and Sons: New York, 2005.

(20) Dasgupta, P. K.; Dyke, J. V.; Kirk, A. B.; Jackson, W. A. Perchlorate in the United States. Analysis of relative source contributions to the food chain. Environ. Sci. Technol. 2006, 40, 6608-6614.

(21) Aziz, C., Borch, R., Nicholson, P., Cox, E. Alternative causes of wide-spread, low concentration perchlorate impacts to groundwater. In Perchlorate Environmental Occurrence, Interactions and Treatment; Gu,B., Coates, J. D. Eds.; Springer: New York, 2006; pp 71-92.

(22) Blount, B. C.; Valentin-Blasini, L.; Osterloh, J. D.; Mauldin, J. P.; Pirkle, J. L. Perchlorate exposure of the US population, 20012002. J. Exposure Sci. Environ. Epidemiol. 2007, 17, 400-407.

(23) Murray, C. W.; Egan, S. K.; Kim, H.; Beru, N.; Bolger, P. M. US Food and Drug Administration's Total Diet Study: Dietary intake of perchlorate and iodine. J. Exposure Sci. Environ. Epidemiol. 2008, 18, 571-580.

(24) Scanlon, B. R.; Goldsmith, R. S. Field study of spatial variability in unsaturated flow beneath and adjacent to playas. Water Resour. Res. 1997, 33, 2239-2252.

ES801737U 